\title{
Comparative Evaluation of Serum Calcium and Magnesium Level in Preeclamptic and Non- Preeclamptic Women in a Tertiary Hospital in Southern Nigeria
}

\author{
Allagoa DO. \\ BMedsc (Pharm) MBBS, FWACS, FMAS, DMAS, CERT ART, Dip HMS, \\ FICS, Consultant Obstetrician/Gynaecologist, Federal Medical Centre \\ Yenagoa, Bayelsa State, Nigeria
}

Agbo OJ.

MBBS, FWACS, Consultant Obstetrician and Gynaecologist, Federal

Medical Centre Yenagoa, Bayelsa State, Nigeria

Orluwene CG.

MBBS,FWACS, Consultant Chemical Pathologist, University of Port Harcourt Teaching Hospital, Port Harcourt, Rivers State, Nigeria

Doi: 10.19044/esj.2018.v14n12p437 URL:http://dx.doi.org/10.19044/esj.2018.v14n12p437

\begin{abstract}
Background: Calcium and magnesium are two micronutrients whose role in the development of preeclampsia has been investigated over the years. There is paucity of studies on the role of serum levels of calcium and magnesium in the development of preeclampsia in south-south Nigeria. Objective: Our study evaluated the serum level of calcium and magnesium in preeclamptic and non preeclamptic women in a Tertiary Hospital in southsouth Nigeria. Methodology: We carried out a comparative study in which 52 preeclamptic and 52 non preeclamptic women, who satisfied the eligibility criteria, were enrolled for the study. Data entry and statistical analysis was done using statistical software (IBM SPSS $®$ for windows version 21.0). Data were analyzed for mean and standard deviation. Comparison of serum levels of elements between the two groups was performed by student t-test, and $\mathrm{P}$ value $<0.05$ was considered as statistically significant. Results: The serum calcium level was statistically lower in the women who developed preeclampsia compared to those who did not $(8.37 \pm 0.91 \mathrm{mg} / \mathrm{dl}$ vs $9.33 \pm 1.15 \mathrm{mg} / \mathrm{dl}, \mathrm{p}<0.001)$. The serum magnesium level was not statistically different between women who had preeclampsia and those who did not $(1.79 \pm 0.24 \mathrm{mg} / \mathrm{dl}$ vs $1.88 \pm 0.37 \mathrm{mg} / \mathrm{dl}, \mathrm{p}=0.102)$. The systolic and diastolic blood pressure showed a significant negative correlation with serum calcium
\end{abstract}


level, unlike serum magnesiun level in those that had preeclampsia. Conclusion: This study showed that women who developed preeclampsia demonstrated reduced serum calcium level and no reduction in serum magnesium level. This study support the hypothesis that hypocalcaemia, unlike hypomagnecaemia, is a possible aetiology of preeclampsia.

Keywords: Hypertension, preeclampsia, calcium, magnesium

\section{Introduction}

Preeclampsia remains a major obstetrics problem all over the world accounting for a large percentage of maternal and perinatal morbidity and mortality (World Health Organization, 2005). The World Health Organization estimates that its incidence is 7 times higher in developing countries than in developed countries and a woman in developing country is 300 times more likely to die from preeclampsia and eclampsia (Engender Health, 2007; Gaym et al., 2011).

Preeclampsia is a common and life threatening complications of pregnancy. The aetiology is not fully understood, but yet treatment modalities are offered. Many theories have been put forward in an attempt to explain the aetiology of preeclampsia; however, the acceptable theories include abnormal trophoblastic tissue invasion of uterine arteries, immunological theory, endothelia cell activation, dietary deficiency, and genetic factors (Shennan, 2007; Kenny, 2011; Miller, 2007).

The relationship between preeclampsia and nutritional deficiencies has been well established; studies have persistently and consistently shown that a relationship exist between the two (Belinzn et al., 1988; Hofmer et al., 1994; Onyegbule et al., 2014; Carroli et al., 1994). An inverse relationship between calcium intake and hypertensive disorders of pregnancy was first reported in 1980 (Hofmer et al., 2010). This was based on the observation that Mayan Indians in Guatemala who traditionally soak their corn in Lime before eating had a high calcium intake and low incidence of preeclampsia (Hofmer et al., 2010). The results of clinical trials showed the aggravation of hypertensive complication and the change in concentration of various trace elements (Belinzn et al., 1988; Hofmer et al., 1994; Onyegbule et al., 2014; Carroli et al., 1994; Hofmer et al., 2010). Calcium and magnesium have a relaxant effects on blood vessels of pregnant women and changes in the concentration of these elements can lead to alteration of blood pressure causing preeclampsia (Carroli et al.,1994; Hofmer et al., 2010). The depletion of tissue stores of magnesium might explain why eclamptic patients tolerate large doses of magnesium as used in contemporary treatment (Sibai; Duley et al., 2010). A very low prevalence of preeclampsia has been reported in 
Ethiopian though a developing country these may be due to the high calcium level in their diets (Hofmer et al., 2010).

Deficiencies of trace elements like calcium and magnesium have been implicated in the aetiology of preeclampsia. There are few studies done to determine the role of serum calcium and magnesium in South-south Nigeria. This study therefore proposes to determine the mean serum levels of calcium and magnesium levels in preeclamptic and healthy women in a tertiary Hospital in South-south, Nigeria. This study also aimed at determining if the difference in serum levels of the trace elements were statistically significant and contributes to the understanding of the role of serum calcium and magnesium in the development of preeclampsia.

\section{Methodology \\ Styudy Area}

This study was carried out in the University of Port Harcourt Teaching Hospital. It is a 650-bed hospital located at Alakhahia in Obio -Akpor local government area of Rivers State, South-South Nigeria, about 15 kilometers from Port Harcourt city along the East-West road. It is a tertiary health center that provides all levels of health care services for Rivers, Bayelsa, Delta, Imo, Abia, and Akwa-ibon States. The obstetrics and gynaecology department is a key department in the hospital with 18 Consultants staff. On the average, between 400 and 450 pregnant women are booked for antenatal care services in the hospital every week, and primidravidae constitute about $41 \%$ of total attendance. Follow up attendance rate is between 250 and 300 patients per week. The delivery rate in the hospital is about 3500 which gives an average monthly of 290 deliveries. The hospital has a chemical pathology department staffed by consultants, resident doctors, Laboratory scientists, and interns. Over 40 different tests are conducted in the chemistry laboratory including serum calcium and magnesium.

\section{Study Design}

This was a comparative case study designed to evaluate the levels of serum calcium and magnesium in pregnant women with preeclampsia and those non preeclamptic in the University of Port Harcourt Teaching Hospital. This study was performed from $1^{\text {st }}$ of July 2015 to $22^{\text {nd }}$ of February 2016. The control and study group was chosen from women attending ante natal care in the University of Port Harcourt Teaching Hospital. The control group was chosen from women who fulfilled the inclusion criteria and were followed up from booking till delivery, but did not develop preeclampsia in the third trimester. On the other hand, the study group was those that were followed up from booking and on development of preeclampsia in the third trimester and that fulfilled other selection criteria which were enrolled in the study. 
A proforma developed for the study was used to record the sociodemographic characteristics, clinical and laboratory data of the patients. The content of the questionnaire include age, marital status, occupation, educational status, religion, parity, booking status, last menstrual period, gestational age, past history of diabetes or hypertension, family history of diabetes or hypertension, presence or absence of pedal oedema, serum calcium level, serum magnesium level, onset of delivery, mode of delivery, birth weight, Apgar score, and admission into special care baby units.

\section{Inclusion Criteria}

1 All those who developed preeclampsia based on: Blood pressure equal to or greater than 140/90 mm Hg on two occasions: 6 hours apart and proteinuria greater than $300 \mathrm{mg}$ in 24 hours urine sample or one plus of protein in 2 midstream urine sample collected 6 hours apart in the $3^{\text {rd }}$ trimester.

2 Singleton fetus

3 Gestational age: third trimester

4 Primigravida

5 No history or evidence of urinary tract infection

6 Age range 18 to 35 years

7 Non diabetics

\section{Exclusion Criteria}

1 Multiple pregnancies

2 Diabetics

3 Pregnancy with renal disease

4 Gestational trophoblastic diseases

5 Chronic hypertension

6 Pregnancy with heart disease

7 Patients already on magnesium sulphate

8 Maternal age greater than 35 years

\section{Sample Size Determination}

Consequently, the sample size was calculated using the formula for comparison of two means:

$$
\mathrm{n}=\frac{(\mathrm{U}+\mathrm{V})^{2}\left(\mathrm{SD}_{1}{ }^{2}+\mathrm{SD}_{1}^{2}\right)}{\left(\mathrm{U}_{1}-\mathrm{U}_{2}\right)^{2}}
$$

Where:

$\mathrm{n}=$ minimum sample size required

$\mathrm{U}=$ one sided percentage point of the normal distribution corresponding to $100 \%$ minus the power. Thus, the power is $90 \%$, and then $\mathrm{U}=1.28, \mathrm{~V}=$ 
percentage point of the normal distribution corresponding to the two sided significance level. Thus at $5 \%$ significance level, $V=1.96$

$\mathrm{SD}_{1}=$ standard deviation in study group $=0.37$

$\mathrm{SD}_{2}=$ standard deviation in control group $=0.69$

$\mathrm{U}_{1}=$ mean of observation in study group $=1.92$

$\mathrm{U}_{2}=$ mean of observation in control group $=2.29$

$\mathrm{n}=\underline{(1.28+1.98)^{2}\left(0.37^{2}+0.69^{2}\right)}$

$(1.92-2.29)^{2}$

$\mathrm{n}=\underline{(10.4976)(0.1369+0.4761)}$

0.1369

$\mathrm{n}=\underline{(10.4976)(0.613)}$

0.1369

$\mathrm{n}=\underline{6.4350}$

0.1369

$\mathrm{n}=47$.

Therefore, a minimum sample size of 47 patients is required in each group. Adjusting for a drop out of $10 \%$, this study will require a total of 104 patients (52patients in each group).

\section{Data Collection And Processing}

The participants in this study were followed up from booking in the second trimester (the minimum gestational age at booking was 16 weeks). Also, informed consent was obtained from each participant before recruitment into the study. A detailed history was taken to ensure each patient fulfilled the selection criteria. Data regarding socio-demographic characteristics, clinical, family history, and laboratory results were recorded in the Proforma. A through clinical examination was done for each patient. The Height and weight of each participant was measured (using a weighing scale ZT-120, METLAR) and the body mass index was calculated by dividing the weight in kilogrammes by the square of the height in meters.

Those in the control group were all normotensive from booking and did not develop preeclampsia. For those in the study group which were followed up from booking and the development of preeclampsia in the third trimester for the first time, the fulfillment of the selection criteria were recruited for the study. Patients in both groups were followed up till delivery.

Blood pressure was measured with the use of manual sphygmomanometer while the patient was in supine position on a couch with a left sided tilt. An appropriate size cuff that covers at least $2 / 3^{\text {rd }}$ of the upper arm was used. The systolic blood pressure was taken at the first point the sound was heardwhile, the diastolic blood pressure was taken as Korotkoff V. (the 
absence of sound). A patient was said to be hypertensive when her blood pressure was equal to or greater than 140/90 mmHg measured at least 6 hours apart. Urine collection was done in the ante natal clinic between 8 to 9 am. Urine samples were collected under the supervision of trained Nurses. Patients were given clean, dry, wide-mouthed, leak-proof containers with their names and number on it. Patients were instructed to clean their vulva with copious clean water, and then part their labia and the first part of the urine voided and to collect the next stream of urine into the urine containers provided. Samples were analyzed for protein estimation using dip stick. Protein estimation was made based on the colour change of the dip stick compared to the corresponding colour chart on the reagent container. The diagnosis of proteinuria was made when two samples of mid-stream urine collected, at least four hours apart, showed one or more plus of albumin. Urine microscopy culture and sensitivity test was routinely done in suspicious cases to exclude infection. Therefore, a patient was said to be preeclamptic when her blood pressure was equal to or greater than $140 / 90 \mathrm{mmHg}$ measured at least six hours apart accompanied by proteinuria of at least one plus.

Blood samples $(5 \mathrm{mls})$ was taken from the ante cubital vein and sent to the laboratory for calcium and magnesium estimation. Blood samples were taken for women in the control group at the time of presentation in the labour ward after an informed consent have been obtained. For patients with preeclampsia, blood samples were collected at the time the diagnosis was first made and before the administration of magnesium sulphate. Then they were followed up till delivery.

At the laboratory, the samples were centrifuged to get the serum which was stored in the refrigerator until the time of analysis. Serum calcium measurement was done using quantitative spectrophotometric analysis. Serum albumin binds to calcium was used to calculate the correct serum calcium level as shown in this formula below.

Corrected total calcium $(\mathrm{mg} / \mathrm{dl})=$ Total calcium measured $(\mathrm{mmol} / \mathrm{L})+$ 0.2(40-albumin $\mathrm{mmol} / \mathrm{L})$.

Serum magnesium level Analysis was done by the direct calmagite method.

Serum calcium was analyzed using an automated electrolytes analyzer (FT1000 Automatic chemical analyzer, fortune limited, Chengdu, China). Magnesium was analyzed using the kit manufactured by Teco Diagnostics, California, $\mathrm{USA}^{62}$.

At birth, data were collected regarding onset of labour, mode of delivery, birth weights, Apgar score, information on whether the baby was admitted into the special care baby unit or were not entered into the Proforma, and the development of any complication. 


\section{Statistical Analysis}

Statistical analysis was done using statistical software (IBM SPSS ${ }^{\circledR}$ for window version 21.0). Data were analysed for mean and standard deviation. Comparison of serum levels of calcium and magnesium between the two groups was performed by student t-test, and $\mathrm{P}$ value $<0.05$ at $95 \%$ confidence interval was considered as statistically significant.

\section{Results}

A total of one hundred and four women were enrolled in the study. The socio- demographic characteristics of the patients were shown in tables 1, 2, 3 and 4 . In the cases group, the age range of women was 18 to 35 years and the mean age was $27.58 \pm 7.34$ years. While in the control group, the age range of women used in this study was 18 to 35 years and the mean age was $26.71 \pm 4.21$ years. The difference was not statistically significant, and the $\mathrm{P}$ value was 0.45 . In the cases group, $11 \%$ were singles while $87 \%$ and $2 \%$ were married and divorced respectively. In the control group, $8 \%$ were singles while $88 \%$ and $4 \%$ were married and divorced respectively. In the cases group, $27 \%$ had primary education, while $44 \%$ and $29 \%$ were educated up to secondary and tertiary level respectively. In the control group, $11.5 \%$ were educated up to primary level, while $46.2 \%$ and $42.3 \%$ had secondary and tertiary education respectively. In the cases group, $94.2 \%$ of them were Christians and $5.8 \%$ Muslems. In the control group, 90.4\% were Christians and 9.6\% Muslems.

The mean gestational age was $36.54 \pm 2.69$ weeks for preeclamptic patients. In the non preeclamptic group, the mean gestational age was $38.67 \pm 1.10$ weeks. There was a significant difference between the two groups. The $\mathrm{p}$ value was 0.01 . The mean body mass index range of the cases group was $28.09 \pm 3.50 \mathrm{Kg} / \mathrm{m}^{2}$. The mean body mass index of the control group was $26.42 \pm 2.42 \mathrm{Kg} / \mathrm{m}^{2}$. There was a statistical difference in body mass index between the two groups. The $\mathrm{p}$ value was $<0.01$. The mean systolic blood pressure of the cases group was $158.88 \pm 11.80 \mathrm{mmHg}$. The mean systolic pressure of the control group was $113.65 \pm 7.15 \mathrm{mmHg}$. There was a statistical difference in systolic blood pressure between the two groups. The $p$ value was 0.01. The mean diastolic blood pressure for the cases group was $101 \pm 8.20 \mathrm{mmHg}$. The mean diastolic blood pressure of the control group was $71.35 \pm 6.57 \mathrm{mmHg}$. There was a statistical difference in diastolic blood pressure between the two groups. The $\mathrm{p}$ value was 0.01 .

The mean serum calcium level in preeclamptic women was $8.37 \pm 0.91$ $\mathrm{mg} / \mathrm{dl}$. The mean serum calcium level in non preeclamptic women was $9.33 \pm 1.15 \mathrm{mg} / \mathrm{dl}$. The $\mathrm{p}$ value was 0.01 . There was a statistical difference in the mean serum calcium level between the two groups. The mean serum magnesium level in preeclamptic women was $1.79 \pm 0.24 \mathrm{mg} / \mathrm{dl}$. The mean serum magnesium level in non preeclamptic women was $1.88 \pm 0.37 \mathrm{mg} / \mathrm{dl}$. The 
$\mathrm{p}$ value was 0.10 . There was no significant difference in mean serum magnesium level between the two groups.

There was a negative correlation between systolic blood pressure and serum calcium level. Pearson correlation $=-0.335, \mathrm{p}<0.01$. There was also a negative correlation between diastolic blood pressure and serum calcium level. Pearson correlation $=-0.256, \mathrm{p}<0.01$. There was no correlation between the systolic blood pressure and serum magnesium level. Pearson correlation = 0.105 , $\mathrm{p}$ value was 0.300 . There was no correlation between diastolic blood pressure and serum magnesium level. Pearson correlation $=-0.170, p$ value was 0.09 .

The onset of labour was spontaneous in $32.7 \%$ of patients with preeclampsia, while it was $73.1 \%$ in the non preeclamptic group. Labour was induced in $28.8 \%$ of the study group, while in the control group, $15.4 \%$ of women had their labour induced. In the control group, $38.5 \%$ had no labour while in the control group $11.5 \%$ had no labour. In the study group, $44.2 \%$ had vaginal delivery as against $88.5 \%$ in the control group. Caesarean section was performed for $55.8 \%$ of women in the cases group, while $11.5 \%$ of women in the control group had caesarean section as their mode of delivery. The mean birth weight in the preeclamptic women was $2.71 \pm 0.70 \mathrm{Kg}$. The mean birth weight in non preeclamptic women was $3.10 \pm 0.43 \mathrm{Kg}$. The $\mathrm{p}$ value was 0.01 . There was significance in birth weight between the two groups. In the cases group, $30.8 \%$ of babies were admitted in the special care baby unit, while in the control group, $7.7 \%$ were admitted.

Table 1. Social and demographic characteristic of the cases and control

\begin{tabular}{|c|c|c|c|c|}
\hline Age (yrs) & Cases & Percentage (\%) & Control & Percentage (\%) \\
\hline $15-19$ & 10 & 19.2 & 4 & 7.7 \\
$20-24$ & 12 & 23.1 & 14 & 26.9 \\
$25-29$ & 11 & 21.2 & 18 & 34.6 \\
$30-35$ & 19 & 36.5 & 16 & 30.8 \\
\hline
\end{tabular}

Table 2. Educational status of cases and control

\begin{tabular}{|c|c|c|c|c|}
\hline Educational status & Cases & Percentage (\%) & Control & Percentage (\%) \\
\hline Primary & 14 & 27.0 & 6 & 11.5 \\
Secondary & 23 & 44.0 & 24 & 46.2 \\
Tertiary & 15 & 29.0 & 22 & 42.3 \\
No formal & 0 & & 0 & \\
education & & & & \\
\hline
\end{tabular}

Table 3. Marital status for cases and control

\begin{tabular}{|c|c|c|c|c|}
\hline $\begin{array}{c}\text { Marital } \\
\text { status }\end{array}$ & Cases & $\begin{array}{c}\text { Percentage } \\
(\boldsymbol{\%})\end{array}$ & Control & $\begin{array}{c}\text { Percentage } \\
(\boldsymbol{\%})\end{array}$ \\
\hline Single & 6 & 11 & 4 & 8.0 \\
Married & 45 & 87 & 46 & 88.0 \\
Divorced & 1 & 2 & 2 & 4.0 \\
\hline
\end{tabular}


Table 4. Religion of cases and control

\begin{tabular}{|c|c|c|c|c|}
\hline Religion & Cases & $\begin{array}{c}\text { Percentage } \\
(\boldsymbol{\%})\end{array}$ & Control & $\begin{array}{c}\text { Percentage } \\
(\boldsymbol{\%})\end{array}$ \\
\hline Christianity & 49 & 94.2 & 47 & 90.4 \\
Muslims & 3 & 5.8 & 5 & 9.6 \\
Others & 0 & & 0 & \\
\hline
\end{tabular}

Table 5. Age of cases and control group

\begin{tabular}{|c|c|c|c|c|}
\hline Parameter & $\begin{array}{c}\text { Cases } \\
\text { Mean } \pm \text { SD }\end{array}$ & $\begin{array}{c}\text { Control } \\
\text { Mean } \pm \text { SD }\end{array}$ & 'p' value & Significance \\
\hline Age (yrs) & $27.58 \pm 7.34$ & $26.71 \pm 4.21$ & 0.45 & Not significant \\
\hline
\end{tabular}

Table 6. Gestational age of cases and control

\begin{tabular}{|c|c|c|c|c|}
\hline Parameter & $\begin{array}{c}\text { Cases } \\
\text { Mean } \pm \text { SD }\end{array}$ & $\begin{array}{c}\text { Control } \\
\text { Mean } \pm \text { SD }\end{array}$ & 'p' value & Significance \\
\hline $\begin{array}{c}\text { Gestational } \\
\text { age }\end{array}$ & $36.54 \pm 2,69$ & $38.67 \pm 1.10$ & 0.01 & Significant \\
\hline
\end{tabular}

Table 7. Body mass index of cases and control

\begin{tabular}{|c|c|c|c|c|}
\hline Parameter & $\begin{array}{c}\text { Cases } \\
\text { Mean } \pm \text { SD }\end{array}$ & $\begin{array}{c}\text { Control } \\
\text { Mean } \pm \text { SD }\end{array}$ & 'p' value & Significance \\
\hline $\begin{array}{c}\text { Body mass } \\
\text { index } \\
\left(\mathrm{kg} / \mathrm{m}^{2}\right)\end{array}$ & $28.09 \pm 3.50$ & $26.42 \pm 2.42$ & 0.01 & Significant \\
\hline
\end{tabular}

Table 8. Blood pressure of cases and control

\begin{tabular}{|c|c|c|c|c|c|}
\hline $\mathrm{p}$ & Parameter & $\begin{array}{c}\text { Cases } \\
\text { Mean } \pm \text { SD }\end{array}$ & $\begin{array}{c}\text { Control } \\
\text { Mean } \pm \text { SD }\end{array}$ & $\begin{array}{c}\text { 'p' } \\
\text { value }\end{array}$ & Significance \\
$\begin{array}{c}\text { blood } \\
\text { pressure }\end{array}$ & $158.88 \pm 11.80$ & $113.65 \pm 7.15$ & 0.01 & Significant \\
$\begin{array}{c}\text { Diastolic } \\
\text { blood } \\
\text { pressure }\end{array}$ & $101 \pm 8.20$ & $71.35 \pm 6.57$ & 0.01 & Significant \\
\hline
\end{tabular}

Table 9. Serum calcium levels of cases and control

\begin{tabular}{|c|c|c|c|c|c|}
\hline $\mathbf{P}$ & Parameter & $\begin{array}{c}\text { Cases } \\
\text { Mean } \pm \text { SD }\end{array}$ & $\begin{array}{c}\text { Control } \\
\text { Mean } \pm \text { SD }\end{array}$ & $\begin{array}{c}\text { 'p' } \\
\text { value }\end{array}$ & Significance \\
\hline & $\begin{array}{c}\text { Calcium } \\
(\mathrm{mg} / \mathrm{dl})\end{array}$ & $8.37 \pm 0.91$ & $9.33 \pm 1.15$ & 0.01 & Significant \\
\hline
\end{tabular}

Table 10. Serum magnesium levels of cases and control

\begin{tabular}{|c|c|c|c|c|}
\hline Parameter & $\begin{array}{c}\text { Cases } \\
\text { Mean } \pm \text { SD }\end{array}$ & $\begin{array}{c}\text { Control } \\
\text { Mean } \pm \text { SD }\end{array}$ & $\begin{array}{c}\text { 'P' } \\
\text { value }\end{array}$ & Significance \\
\hline $\begin{array}{c}\text { Magnesium } \\
(\mathrm{mg} / \mathrm{dl})\end{array}$ & $1.79 \pm 0.24$ & $1.88 \pm 0.37$ & 0.10 & $\begin{array}{c}\text { Not } \\
\text { significant }\end{array}$ \\
\hline
\end{tabular}


Table 11. Onset of labour of cases and control

\begin{tabular}{|c|c|c|c|c|}
\hline Onset of labour & Cases & $\begin{array}{c}\text { Percentage } \\
(\mathbf{\%})\end{array}$ & Control & $\begin{array}{c}\text { Percentage } \\
(\boldsymbol{\%})\end{array}$ \\
\hline Induced & 15 & 28.8 & 8 & 15.4 \\
Spontaneous & 17 & 32.7 & 38 & 73.1 \\
No labour & 20 & 38.5 & 6 & 11.5 \\
\hline
\end{tabular}

Table 12. Mode of delivery of cases and control

\begin{tabular}{|c|c|c|c|c|}
\hline Mode of delivery & Cases & $\begin{array}{c}\text { Percentage } \\
(\boldsymbol{\%})\end{array}$ & Control & $\begin{array}{c}\text { Percentage } \\
(\boldsymbol{\%})\end{array}$ \\
\hline Vaginal & 23 & 44.2 & 46 & 88.5 \\
$\begin{array}{c}\text { Caesarean section } \\
\text { Forceps/ Vacuum }\end{array}$ & 29 & 55.8 & 6 & 11.5 \\
\hline
\end{tabular}

Table 13. Maternal complications of cases and control

\begin{tabular}{|c|c|c|}
\hline Complications & Cases & Control \\
\hline Abruption & 3 & 0 \\
Intra uterine growth restrictions & 6 & 2 \\
Eclampsia & 2 & 0 \\
\hline
\end{tabular}

Table 14. Birth weight of cases and control

\begin{tabular}{|c|c|c|c|c|}
\hline Parameter & $\begin{array}{c}\text { Cases } \\
\text { Mean } \pm \text { SD }\end{array}$ & $\begin{array}{c}\text { Control } \\
\text { Mean } \pm \text { SD }\end{array}$ & $\begin{array}{c}\text { 'P' } \\
\text { value }\end{array}$ & Significance \\
\hline $\begin{array}{c}\text { Birth } \\
\text { weight }\end{array}$ & $2.71 \pm 0.70$ & $3.10 \pm 0.43$ & 0.01 & Significant \\
\hline
\end{tabular}

Table 15. Admission into special care baby unit

\begin{tabular}{|c|c|c|c|c|}
\hline Parameter & Cases & $\begin{array}{c}\text { Percentage } \\
(\boldsymbol{\%})\end{array}$ & Control & $\begin{array}{c}\text { Percentage } \\
(\boldsymbol{\%})\end{array}$ \\
\hline $\begin{array}{c}\text { Admission } \\
\text { into special } \\
\text { care baby unit }\end{array}$ & 16 & 30.8 & 4 & 7.7 \\
\hline
\end{tabular}

\section{Discussion}

Calcium and magnesium are elements which are deficient in pregnant women in developing countries. This usually occurs due to reduced dietary intake which is common in developing countries. Our study showed a statistical significant lower calcium level with no significant changes in magnesium level.

This study did not show any statistical significance in age between the two groups, which was also noted by another study in pregnant women in Abakaliki, South-East Nigeria. However, the study reported no significant difference in age between preeclamptic and healthy women (Ugwuja et al., 2016). Earlier studies of Onyegbule et al. (2014) and Akinloye et al. (2010) were keeping with the findings of our study. However, in another work by Kanagal et al. (2014) in India, there was a significant difference in age between preeclamptic patients and non preeclamptic patients. This may be due to 
difference in age, diet, and study population. Increase in maternal age is a wellestablished risk factor for the development of preeclampsia (Jido \& Yakasai, 2014; Anorlu et al., 2005). As parity increases, age also increases.

Obesity predisposes a woman to the development of preeclampsia and a relationship between increasing body mass index and the risk of preeclampsia is well established (Jido \& Yakasai, 2014; Kaklina et al., 2009). The study revealed a very strong association between the development of preeclampsia and body mass index. Akinloye et al also found a significant higher body mass index in the preeclamptic. The finding of this work was consistent with previous study (Jido \& Yakasai, 2014). However, the result of this study was not keeping with the findings of Ugwujaet al. (2016) which showed a significantly higher body mass index among non preeclamptic women. The study concluded that the reason for the higher body mass index in normotensive patients is obscure. However, genetic factors may be implicated.

This study showed that the patients who had preeclampsia have their babies delivered at a lower gestational age. The reason being that the ultimate cure for preeclampsia is delivery to prevent the development of maternal or fetal complications. The decision to deliver depends on the severity of the disease, gestational age, maternal and fetal complications. Thus, delivery is not always in the interest of the baby (Miller, 2007; Repke \& Sibai, 2009). The result of this study is consistent with an earlier report (Kanagal et al., 2014). The report of this study is not in agreement with a similar study (Ugwuja et al., 2016) that reported no significant difference between pregnant women with preeclampsia and non preeclamptic in terms of gestational age at delivery. Similar reports in the past had same findings (Gol Mohammed et al., 2008; Naser \& Ziad, 2000).

The results from this study showed a mean systolic blood pressure of $158.88 \pm 11.80 \mathrm{mmHg}$ and a mean diastolic blood pressure of $101 \pm 8.20 \mathrm{mmHg}$ in preeclamptic patients in contrast to a mean systolic blood pressure of $113.65 \pm 7.15 \mathrm{mmHg}$ and a mean diastolic blood pressure of $71.35 \pm 6.57 \mathrm{mmHg}$ in control group. This was consistent with an earlier investigation by Sukonpan et al. (2005) who reported a mean systolic blood pressure of $155.50 \pm 12.18 \mathrm{mmHg}$ and a mean diastolic blood pressure of $108.18 \pm 10.89$ $\mathrm{mmHg}$ in preeclamptic patients, and also a mean systolic and diastolic blood pressure of $108 \pm 6.50 \mathrm{mmHg}$ and $68.60 \pm 8.19 \mathrm{mmHg}$ in the control group respectively. The slight differences may be due to ethnic differences. The implication of this is that the pathogenesis and severity of complications following preeclampsia varies from one region to the other (Akinloye et al., 2010).

The birth weight of babies was significantly lower in preeclamptic patients. The reason is that hypertensive disorders during pregnancy are 
associated with vasculopathy, which also affects the placenta and the relative placenta insufficiency wound. However, this is also expected to affect the fetal birth weight to some degree. There were similar findings in earlier studies (Jido \& Yakasai, 2014; Naser \& Ziad, 2000; Sukonpan \& Phupong, 2005).

In this study, the mean serum level of calcium in the control group was $9.33 \pm 1.15 \mathrm{mg} / \mathrm{dl}$, while the mean serum calcium level in the cases group was $8.37 \pm 0.91 \mathrm{mg} / \mathrm{dl}$. Calcium is an important element as it is necessary for muscle contraction and neuronal activity. The blood pressure changes evident in preeclampsia can be attributed to the change in serum calcium level. Decrease in serum calcium levels led to an increase in intracellular calcium. This led to constriction of blood vessels and an increase in vascular resistance and also a resultant increase in blood pressure (Sukonpan \& Phupong, 2005).

The major finding in this study was the significant lower level of mean serum calcium level in preeclamptic women $8.37 \pm 0.91 \mathrm{mg} / \mathrm{dl}$ compared to non preeclamptic women $9.33 \pm 1.15 \mathrm{mg} / \mathrm{dl}$. Akinloye et al. (2010) had a similar finding which was supported by other previous reports (Kanagal et al., 2014; Kumru et al., 2003; Abdallah \& Abdiabo, 2014). However, this was in disagreement with the study by Gol Mohammed et al. (2008) who reported that there was no difference in the level of serum calcium level between preeclamptic and non preeclamptic women. The difference in serum calcium levels obtained in different studies may be due to the difference in the study design, analytical technique, difference in population characteristics such as age, race, ethnicity, socio-economic status as well as country and region of residency (Essom et al., 2012). This study supported the hypothesis that hypocalcaemia might be a factor in the development of preeclampsia.

The serum magnesium level in this study was $1.79 \pm 0.24 \mathrm{mg} / \mathrm{dl}$ for the preeclamptic women. The mean serum magnesium level was $1.88 \pm 0.37 \mathrm{mg} / \mathrm{dl}$ for non preeclamptic women. Decreased in serum magnesium level has been considered as the cause of preeclampsia. The success of magnesium therapy as a treatment for eclamptic seizure and the known effect of magnesium on vascular smooth response in-vitro suggested that magnesium might be deficient in women with preeclampsia (Jido \& Yakasai, 2014).

An important finding in this study shows that there was no difference in the mean serum magnesium level $(1.79 \pm 0.24 \mathrm{mg} / \mathrm{dl})$ in the preeclamptic and non preeclamptic $(1.88 \pm 0.37 \mathrm{mg} / \mathrm{dl})$. The findings of this study are in accordance with previous studies (Gol Mohammed et al., 2008; Kumru et al., 2003). This was supported by an earlier work by Kanagal et al in Indian where most of the patients used for the study were from the lower class strata with poor dietary consumption of calcium and magnesium rich food. Thus, the findings in this study were not in agreement with previous studies (Onyegbule et al., 2014; Akinloye et al., 2010). The difference in value of magnesium 
obtained in various studies may be due to variation in the study population and dietary intake.

This study has potential limitations and issues attracting criticism. First, the dietary intake of preeclamptic women was not taken prior to the commencement of the study to ascertain their calcium and magnesium level. Another limitation of this study is the non-use of quantitative method in detecting proteinuria. The direct (Calmagite) method which is easier and cheaper was used in this study instead of the ion-selective electrode which is better, but expensive in the analysis of serum calcium and magnesium levels. However, findings from this study remain relevant and add to evidence on the subject matter.

\section{Conclusion}

1. This study showed that in preeclamptic women, serum calcium is significantly reduced.

2. This study support the hypothesis that hypocalcaemia is a possible aetiology of preeclampsia.

3. The study revealed that in preeclamptic women, serum magnesium level is not significantly reduced.

4. This study did not support the hypothesis that hypomagnesaemia is a possible cause of preeclampsia.

5. There was a negative correlation between serum calcium level and systolic or diastolic blood pressure.

6. There was no negative correlation between serum magnesium level and systolic or diastolic blood pressure.

\section{Recommendation}

Based on the results obtained from this study, the following recommendations were made:

1. Educating women of reproductive age on the importance of micronutrients in the prevention of preeclampsia.

2. Routine screening and close surveillance of micronutrients, especially calcium during antenatal period.

3. Dietary supplementation with calcium should be done at least in susceptible women, especially in developing countries.

4. More studies should be carried out in this field.

\section{References:}

1. Abdallah, A. \& Abdiabo, AA. (2014). Assessment of serum calcium, magnesium, copper and zinc levels in Sudanese pregnant women with preeclampsia. Advances Res J Med Sci. 
2. Akinloye et al. (2010). Evaluation of trace elements in pregnant women with preeclampsia. Afri J Biotech 2010;9(23):5196-5202, 3(2):33-36.

3. Anorlu, RI., Iwula, NC., \& Odum, CU. (2005). Risks factors for preeclampsia in Lagos, Nigeria; 45(4):278-282.

4. Belinzan, JM., Villar, J., \& Repke, J. (1988). The Relationship between calcium intake and pregnancy induced hypertension: up to date evidence. America J Obstet Gynaecol; 158:898-902.

5. Carroli, G., Duley, L., Belizan, JM., \& Villar, J. (1994). Calcium supplementation during pregnancy ; A systemic review of randomized control trials. British J Obstet Gynaecol:753-8.

6. Duley, L., Mater, HE., Almeria, MQ., \& Hall, DR. (2010). Alternative magnesium sulphate regime for women with preeclampsia and eclampsia: Cochrane data base of systemic review. Issue 8 Art. No CD007388.DOI:10.1002/14651858.CD007388.Pub2.

7. Engender Health (2007). BALANCING THE SCALES.Expanding treatment for pregnant women with life threatening hypertensive conditions in developing countries. A report on Barriers to treat preeclampsia and eclampsia: Engender Health.

8. Essom, AE., Heshan, HA., \& Hani, MA. (2010). Maternal serum calcium and trace elements; copper and zinc among preeclamptic women in Cairo, Egypt. The Egyptian Journal of Hospital. Medicine; $41 ; 520-531$.

9. Gaym, A., Barley, P., Pearson, L., Admasu, K., \& Gebrehiwot, Y. (2011). Disease burden due to preeclampsia/eclampsia and Ethiopian health system response. Int J Gynecol Obstet; 115:112-116.

10. Gol Mohammed, C., Amirabi, A., Yazdian, M., \& PashaPourl, N. (2008). Evaluation of serum calcium, magnesium, copper and zinc levels in women with preeclampsia. Int J Med Sci.; 33(4):231-234.

11. Hofmer, G., Duley, L., \& Attalla, AN. (1994). Dietary calcium supplementation for prevention of preeclampsia and related problem. British J Obstet Gynaecol; 101(9):753-8.

12. Hofmer, G., Lawrie, TA., Atalla, AN., \& Duley, L. (2010). Calcium supplementation during pregnancy for preventing hypertensive disorder and related problems. Cochrane data base of systemic review, issue 8. Art.no CD001059.DOI:10.1002/14651858.pub3.

13. Jido, TA. \& Yakasai, IA. (2014). Preeclampsia: A review of the evidence. Ann Afri Med; 12:75-85.

14. Kaklina, EV., Ayala, C., \& Callagha, WH. (2009). Hypertensive disorder and severe obstetric morbidity in the in the United State of America. Obstet Gynaecol; 113:1299:306. 
15. Kanagal, DV., Rajesh, A., Rao K et al. (2014). Levels of serum calcium and magnesium in preeclamptic and normal pregnancy: A study from coastal India. J Clin and Diag Res 2014; 8(7):0001-0004.

16. Kenny, CL. (2011). Preeclampsia and other disorders of placentation. In: Baker PN, Kenny CK (eds) Obstetrics by ten teachers $19^{\text {th }}$ edition. London: Holder Arnold; 120-131.

17. Kumru, S., Aydin, S., Simsek, M et al. (2003). Comparison of serum zinc, calcium and magnesium levels in preeclamptic and healthy pregnant women. Biol Trace Elem Res; 93: 105-12.

18. Miller, D. (2007). Hypertension in pregnancy. In:Decherney AH, Nathan L, Goodwin TM, Laufer N(eds) Current Diagnosis and Treatment Obstetrics and Gynaecology $10^{\text {th }}$ Edition, International ED. New York: McGraw-Hill; 318-327.

19. Naser, OM. \& Ziad, MS. (2000). Does serum calcium in preeclampsia and normal pregnancy differ? Saudi J Med.2000; 22(10): 868-871.

20. Onyegbule, OA., Udo, JN., Ezidigboh et al. (2014). Comparison of serum levels of calcium and magnesium among preeclamptic and normotensive pregnant women at Nnamdi Azikiwe University Teaching Hospital Nnewi, Nigeria.Int J Res Med Sci; 2(2):404-408.

21. Repke, JT. \& Sibai, MB. (2009). Preeclampsia and eclampsia: Seven management challenges and zero short-cut. The family Pract J; 21(4):578-85.

22. Sibai, BM. Diagnosis and management gestational hypertension and preeclampsia ACOG international newsletter volume 102. Issue 1.

23. Shennan, A. (2007). Hypertensive disorders. In: Edmonds DK (Ed) Dewhurst's textbook of Obstetrics and Gynaecology for post graduate $7^{\text {th }}$ edition. Oxford: Blackwell publishing Oxford; 227-235.

24. Sukonpan, K. \& Phupong, V. (2005). Serum calcium and magnesium in normal and preeclamptic pregnancy. Arch Gynaecol Obstet; 273(1):12-16.

25. Ugwuja, IE., Famurewa, AC., \& Ikaraoha, CI. (2016). Comparison of serum calcium and magnesium between preeclamptic and normotensive pregnant women in Abakaliki, south east, Nigeria. Ann Med Health Sci Res;6:33-7.

26. World Health Organization (2005). The world health organization report 2005. Make every mother and child count Geneva: World Health Organization. 